\title{
Gap Filling
}

\section{Welcome by the Editor-in-Chief}

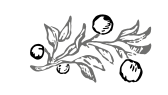

Journal of Economic Literature (JEL) codes: A11, B41, E12, H12

Keywords: economic policy, crisis management, consolidation, renewal of the economic education, Hungary

Between 1990 and 2015, the Hungarian economy closed the gap to the European Union average by improving half a percent per annum, and approached the seventy percent performance of the latter from below, while Austria (permanently seen in Hungary as a benchmark) is already at a hundred and thirty percent of the EU-28 average development. Hungary's gap to Austria in terms of development is also thoughtprovoking in light of the fact that back in 1867, in the favourable business climate offered by the Austro-Hungarian Compromise, Hungary's level of development still rivalled those of the Austrian and Czech territories. However, up to this very day, we have not managed to return to these piping times of peace.

Following the change of regime, Hungary underwent three crises. It was exposed to inappropriate economic policy actions in the period of transition to a market economy, and to the shock caused by "market reforms" between the late 1980s and the early 1990s. Then it had to suffer the effects of the 1995 economic policy adjustment actions (hallmarked by the name of Lajos Bokros), which can be considered as the textbook example of austerity measures, and to the consequences of government overspending between 2002 and 2006, a rampage that plunged the central and local governments as well as households into a debt trap. And finally, on top of the latter, i.e. the adjustment package of the convergence trajectory launched in the autumn of 2006 (which actually meant additional austerity measures), the crisis that "fed through" from the Anglo-Saxon markets first to Western Europe and then to Hungary was only the cherry on the cake, and sealed the fate of the Hungarian economy, excessively relying on Neo-liberal bases.

A lesson to learn from the twenty five years that followed the change of regime is that the gap cannot be closed and neither success nor stability can be achieved by an imported economic policy. Also, no rise is to be expected by entering into alliance with weakening great powers. As a third conclusion, there is no governance against the nation. The society and domestic businesses cannot be made to pay the total price of the transformation and reforms alone. As a timeless rule, successful economic policy requires social support. 


\section{Gap Filling - Welcome by the Editor-in-Chief}

After 2010, for eight years now, it goes without saying that an independent economic policy is the national therapy that has created financial consolidation and economic growth. In addition to the weakening European Union, we have found new trading partners. We have reduced the external dependence of our economy, on the one hand, while expanding the range of countries that have an effect on our relations beyond the borders of the European Union, on the other. The resources required for financial consolidation and structural reforms were provided or the budget was topped up from a circle of multinational companies - who did not pay taxes in proportion to their strength - by means of an economic policy based on the ideas of $\mathrm{J}$. M. Keynes.

However, the fact that the methodology of these outstanding performances are not taught in higher education can be considered as an intellectual failure, as nonimprovement in the knowledge capital impedes progress and genuine competitiveness. Up to this moment Hungarian higher education, and especially social science, is characterised by the lack of a regulatory environment and the failure to insert the Hungarian model into the historical and international space. The economic policy applied by the Hungarian Government and the National Bank of Hungary is not yet taught in its context at any of the Hungarian universities. The curriculum does not reveal the essence of the Hungarian model relying on public burden sharing, proactive governmental economy engineering, regulation and control. To be more specific, comprehensive knowledge about the equitable collection of taxes and contributions, family and home creation subsidies, other social achievements, the policy of managing national wealth, the successful financial consolidation, the multiple objectives and means adopted by the National Bank of Hungary, and the monetary policy in support of good governance is not included in the university curriculum. Thus, the economic achievements are unfortunately not preserved as values, and as a result of the blocking activity pursued by universities engaged in social sciences, impairment will take place.

The journal of social sciences Polgári Szemle endeavours to mitigate this intellectual deficiency by providing new and up-to-date knowledge to fill the gap. In this issue extensive account is given of the outcomes of our most recent research into public finances. A commemorative article by Count István Bethlen is published about the Reformation, to celebrate its 500th anniversary, its economic impacts and facts of Hungarian relevance. All these are done in order to fill the gap as neither the efforts made in public finances, the events that take place in the economy nor pathfinders of an economy built on ethical and Christian principles have been inserted into the curriculum. This is despite the fact that the works of economic thinkers and professors like Luigino Bruni, Stefano Zamagni (Bruni-Zamagni, 2007), Helen J. Alford O.P., Michael J. Naughton (Alford-Naughton, 2001), all available in Hungarian translation, and the writings of Sarolta Laura Baritz OP (Baritz, 2016), all focusing on human welfare, are the forerunners of a new or reviving thinking based on Bible teachings, similarly to professors Dembinski and Zamagni, who are reinvigorating the doctrines of Antonio Genovesi (Genovesi, 1765-1769). We Hungarians also wish to 
leave the crisis behind, prevent wars and create a new, sustainable production method that serves the general benefit of humankind, advocated by the renowned scientist Paul H. Dembinski, whose book entitled Ethics and Responsibility in Finance, published in 2017, is another breakthrough and an evidence that the Neoliberal production method is out of date (Dembinski, 2017). Where are all these in the curricula of Hungarian universities? Where are the books written by the experts of or with support from the academic workshop of the National Bank of Hungary included in social science curricula or even recommended as additional reading?

Worldwide, there is an enormous demand for academic research and university training in the new methodological fundamentals that follow and track the first years of the crisis (2007-2008). The researchers and students of the London School of Economics, dissatisfied with the economic dogmas, call for a remedy of this deficiency, and five hundred years after Martin Luther nailed his theses to the door of All Saint's Church in Wittenberg, the researches and students who want change have done something similar. They summed up their demands in 33 points. The reason is that the world is struggling with poverty, inequalities, an environmental crisis and financial instability, and in their opinion, economics could do more to help solve the problems. We can say that those national economies will become successful and competitive that are able to demonstrate scientific results after penetrating deep into problems and can find solutions, write textbooks and teach them at universities. The current favourable GDP, exchange rate and inflation can only be sustained in Hungary as well as other countries if training runs deep into changes and can transmit the methodology of renewal. The Neo-liberal economics that caused Hungary's financial and economic failure should not be considered as a religion or belief, but as a research area, a problem to be solved and unravelled, scientifically investigated, criticized and corrected. It is no solution that the advocates of the obsolete Neo-liberal production method withdraw and are secluded in their ivory towers, and elbow out the researchers organised around the London School of Economics, the National Bank of Hungary or Polgári Szemle from academic positions, blacklist their books and pretermit their existence.

In the political space that will re-open from 2018, the training methodology should be re-arranged in higher education in Hungary, too.

In the series of our successes and new challenges, it is my unhappy duty to report that we have bidden farewell to Béla Kolozsi, sociologist and psychologist, renowned researcher of international relations and retired ambassador, who died in November 2017, at the age of 73, following a short disease. Béla Kolozsi participated in the work of numerous higher education institutions from the training of physicians through studies in communication and international relations to acting as head of the Department of Sociology at the University of Miskolc. In the last decade of his university career, he was a titular associate professor of the Institute for International Relations and Politics at the Pázmány Péter Catholic University. He was a visiting professor of the University of Lyon and a visiting researcher in Oxford. He was a founding member of the Hungarian Democratic Party. Between 1992 and 1994, he headed the Department of Strategic Analysis and Planning at the Ministry of Foreign Affairs, and 
between 1999 and 2004, he undertook diplomatic service abroad: he was Hungary's ambassador to Sophia. The very last of more than a hundred of his scientific studies was published in the 2017 special issue of Polgári Szemle, about the autonomous territory of Szeklerland. Rest in peace, we will remember you.

\author{
Professor Csaba Lentner, \\ Editor-in-chief of Polgári Szemle
}

\title{
REFERENCES
}

Alford, Helen J. O.P. - Naughton, Michael J. (2001): Managing as if Faith Mattered. Christian Social Principles in the Modern Organization. University of Notre Dame Press, Notre Dame, Indiana. In Hungarian: Menedzsment, ha számít a hit. Keresztény társadalmi elvek a modern korban. Kairosz Kiadó - Mária Rádió Kiadó, Budapest, 2009.

Baritz, Sarolta Laura OP (2016): Háromdimenziós gazdaság. Lehet gazdálkodni erényetikai paradigmában. [Three-dimensional Economy. Economy Management in an Virtuous Ethical Paradigm.] Kairosz Kiadó, Budapest.

Bruni, Luigino - Zamagni, Stefano (2007): Civil Economy. Efficiency, Equity, Public Happiness. Verlag Peter Lang, Bern. In Hungarian: Civil gazdaság. Hatékonyság, méltányosság, köz-jóllét. L'Harmattan Kiadó, Budapest, 2013.

Dembinski, Paul H. (2017): Ethics and Responsibility in Finance. Routledge, Abingdon, https://doi. org/10.4324/9781315205342. In Hungarian: Etika és felelôsség a pénzügyi életben. Kairosz Kiadó, Budapest, 2018.

Genovesi, Antonio (1765-1769): Lezioni di commercio o sia di economia civile. In Hungarian: Értekezések a kereskedelemról, avagy a polgári gazdaságról. Kairosz Kiadó, Budapest, 2016. 